\title{
Using State and Metropolitan Area House Price Cycles to Interpret the U.S. Housing Market
}

\author{
Yolanda K. Kodrzycki and Nelson Gerew
}

\begin{abstract}
:
This brief examines the numerous house price cycles in states and metropolitan areas since the 1970s, drawing lessons that may be informative for analyzing and projecting national patterns. It finds that house sales volumes, new home construction, and mortgage delinquencies have provided leading indicators when a statewide house price boom was nearing an end, but that house prices have rarely decreased in the absence of a state recession. The median relationship suggests that the national OFHEO house price index could keep increasing well into 2007, given the sales and construction declines and the increases in delinquencies observed to date, and absent other factors that weaken the economy. However, the lead-lag relationships have varied considerably across states and time periods, indicating that turning points in house prices are difficult to predict precisely.
\end{abstract}

Next, the brief examines the empirical relationship between metropolitan-area house prices and measures of their deviation from justifiable values, as derived from economic models. It finds that the probability of a house price decline in metropolitan areas has depended on both the extent to which housing was overvalued two to three years earlier and on changes in market fundamentals that affect housing. An extrapolation of these results suggests that national house price increases are likely to be approximately flat for the remainder of 2006. Estimates for 2007 vary, depending on assumptions regarding mortgage interest rates, personal incomes, and apartment rents, and on one's views on how such factors influence housing markets. In addition, the brief also cautions that the economic models developed to date provide only partial explanations of past house price movements.

On the whole, the results can be interpreted as adding support for the view that average U.S. house prices are likely to be fairly flat in 2006 and 2007. Because house prices are subject to inexplicable movements, this conclusion should be viewed as a plausible extrapolation using historical evidence rather than a forecast. An additional caveat is that mortgage markets and other institutional factors may have changed sufficiently so as to alter the relationship between house prices and the economy compared with what existed in past cycles.

Yolanda K. Kodrzycki is a Senior Economist and Policy Advisor and Nelson Gerew is a Research Associate, both at the Federal Reserve Bank of Boston. Their email addresses are yolanda.kodrzycki@bos.frb.org, and nelson.gerew@bos.frb.org, respectively.

This brief is based on materials presented in briefings to the President and Board of Directors of the Federal Reserve Bank of Boston from January to May 2006, with selective updates to reflect new data. These updates do not have a material effect on the findings.

This brief, which may be revised, is available on the web site of the Federal Reserve Bank of Boston at http://www.bos.frb.org/economic/ppb/index.htm.

The views expressed in this brief are solely those of the authors and do not necessarily reflect the official position of the Federal Reserve Bank of Boston or the Federal Reserve System. 
Housing markets have provided a source of strength to the U.S. economy since the mid1990s, including during the recession of 2001. Rising home prices have contributed positively to household wealth over this period, thereby providing an impetus to consumer spending. Now, various indicators show a deterioration in housing markets. Among these recent shifts, house price appreciation has slowed, spurring the debate over the magnitude of the looming house price correction and its effects on the economy. Because U.S. home prices have not experienced a true "bust" for a great many years, discussions concerning future movements suffer from a lack of relevant precedents.

In general, the timing of house price declines is difficult to foresee because buyers and sellers do not respond immediately and fully to changing market information. Instead, in a booming market, house price increases "take on a life of their own." To date, researchers have not been able to explain-let alone predict-the timing of when deteriorating market fundamentals outweigh the impact of non-fundamentals (such as extrapolations of past appreciation) in determining house prices.

This brief examines the numerous house price cycles in states and metropolitan areas since the 1970s, drawing lessons that may be informative for analyzing and projecting national patterns. It finds that house sales volumes, new home construction, and mortgage delinquencies have provided leading indicators when a statewide house price boom was nearing an end, but that house prices have rarely decreased in the absence of a state recession. The median relationship suggests that the national OFHEO house price index could keep increasing well into 2007, given the sales and construction declines and the increases in delinquencies observed in data released to date, as of October 2006. However, the lead-lag relationships have varied considerably in past housing cycles, underscoring the uncertainty inherent in anticipating turning points in house prices. 
Next, the brief examines the empirical relationship between metropolitan area house prices and measures of their deviation from justifiable values, as derived from economic models. It finds that the probability of a house price decline in metropolitan areas has depended on both the extent to which housing was overvalued two to three years earlier and on changes in market fundamentals that affect housing. Assuming continued increases in personal incomes, an increase in mortgage interest rates in 2006, and flat apartment rents, an extrapolation suggests that national house price increases are likely to be in the range of 1 to 3 percent in 2006 and 2 to 5 percent in 2007. These extrapolations are based also on some assumptions concerning how to aggregate the prevalence of metro area house price increases and decreases into a percent change in house prices for the nation. At each step of the analysis, the brief demonstrates the extent to which past movements in house prices can be explained by the available data and models, so as to highlight the imprecision of any forward-looking estimates.

On the whole, the results can be interpreted as supporting the view that average U.S. house prices are likely to be fairly flat in 2006 and 2007. Because state and metro-area house prices are subject to inexplicable movements, however, this conclusion should be viewed as a plausible extrapolation based on historical evidence rather than a forecast. It is also possible that mortgage markets and other institutional factors may have changed sufficiently to alter the relationship between house prices and the economy compared with what existed in past cycles.

\section{Why Look at States and Metro Areas?}

A variety of price concepts can be used in analyzing housing markets. ${ }^{1}$ This policy brief focuses on the widely cited home price indexes published by the Office of Federal Housing Enterprise Oversight (OFHEO), which are available for the U.S., all 50 states

\footnotetext{
${ }^{1}$ For comparisons of alternative measures, see Jonathan McCarthy and Richard W. Peach, "Are Home Prices the Next 'Bubble'?" Federal Reserve Bank of New York Economic Policy Review, December 2004, pp. 1-17. In addition, the Case-Shiller home price indexes are discussed at www.cme.com/housing.
} 
and the District of Columbia, and 379 metropolitan areas. The Wall Street Journal recently drew added attention to the OFHEO series when it surveyed economists on their yearahead predictions for the national index. ${ }^{2}$

The OFHEO indexes are derived from mortgage transactions data for single-unit properties supplied by the Federal National Mortgage Association (Fannie Mae) and the Federal Home Loan Mortgage Corporation (Freddie Mac). They are repeat-sales indexes, meaning that they measure average price changes based on sales or refinancings of the same properties at different points in time. As compared with the median home price data collected by realtors, the OFHEO measures of price change are less sensitive to the mix of homes sold at any given date.

Nationwide, homes appreciated at an annualized rate of 11 percent between the fourth quarter of 2002 and the fourth quarter of 2005, in an aberration from historical trends (Figure 1). Home prices rose faster than at any time in the last three decades except the late 1970s, which were characterized by generally high inflation. In real terms, the 9percent annualized rate of house price inflation during these three years was unprecedented in the 31-year history of the OFHEO index.

Although there appear to have been numerous house price downturns in the United States through the 1940s, house price decreases on a nationwide basis have been uncommon during the period for which we have reliable, regularly issued estimates. ${ }^{3}$ Nominal values have never fallen in the OFHEO series, although appreciation was minimal in 1990 and 1994 (1.2 percent and 0.8 percent, respectively). There have been

\footnotetext{
2 "Economists See Housing Market Cooling Further" by Phil Izzo, Wall Street Journal, September 28, 2006, p. A2.

${ }^{3}$ Robert Shiller has constructed a long-term index of U.S. house prices by combining four indexes, resulting in a series dating back to 1890. The series contains frequent declines in U.S. real home prices, but only two sizeable declines since 1960. See Shiller, "Long Term Perspectives on the Current Boom in House Prices" The Economists' Voice, Berkeley Electronic Press, March 2006.
} 
only three episodes of declining real house values during this time period: 1975, 1979_ 82, and 1989-94. Each of these instances overlapped to some degree with a national recession and a period of Federal Reserve tightening. In addition, real house prices flattened in 1996-97.

By contrast with national series, price indexes that track smaller areas show both sizeable price increases and price declines. For example, between 1979 and 1995, 38 states experienced at least one three-year period in which nominal appreciation was at least twice the long-term average for the state.

Metro area house prices have also shown dramatic gyrations. Figure 2 presents the available data for several of the more volatile areas-Boston, Los Angeles, New York, and San Francisco. Nominal home price increases in Boston and San Francisco during some periods of the 1980s were even greater than they have been in the last several years. These peaks were followed by periods of considerable price decline, with Boston homes decreasing in value through 1992, including a 7-percent decline in 1990 alone. San Francisco and Los Angeles also experienced nominal year-over-year declines from 1990 to 1994, with maximum annual declines of 5 percent and 8 percent, respectively.

The advantage of examining house prices at the state or metropolitan area levels is that the larger sample of areas, as well as their volatility, may shed greater light on the timing-or even the causes-of house price swings than the smoother national data can provide. Many of the same economic indicators are available for states as for the nation. Thus, state house price patterns can be compared with other measures of the health of the housing market and the general economy. Such an analysis-which is undertaken below-can provide information on housing market dynamics that may be useful in analyzing incoming data for the nation as a whole.

An argument for using city data, on the other hand, is that metropolitan areas form natural units for analyzing housing markets. Previous studies have compared actual 
versus "fundamental" values of housing in different localities, and their results have been interpreted as indicating the direction of future price changes. This policy brief investigates the degree to which overvaluation measures can account for past house price movements. If these estimates can withstand historical scrutiny, their implicit predictions for house prices-local or national-should be taken more seriously than if they do not.

One obvious drawback of a disaggregated approach is that ups and downs in state and local housing markets do not translate directly into implications for the nation as a whole. The premise behind this policy brief is that it is possible to aggregate local price patterns into (admittedly imperfect) indicators of national price movements. For example, if house prices are expected to fall in a large percentage of states or metro areas, or in localities accounting for a large share of the U.S. population, nationally measured house prices arguably would be at risk of falling.

\section{Defining House Price Booms and Busts}

In examining house price cycles, it is useful to begin by establishing some working definitions. This paper uses two alternative definitions of a house price boom, the first of which encompasses many more historical instances than the second. Under the first definition, a boom is an episode during which nominal house prices over a three-year period increase at an annualized rate that is at least twice the series average. Most popular discussions of housing markets refer to nominal prices, and comparing each state or locality's price increase to its own average is a way of normalizing for differences in long-run price trends across geographies.

Under the other definition used in this policy brief, a boom refers to real house price appreciation of 30 percent or more over a three-year period. Under this concept, the emphasis is on house prices as distinct from general inflation in the national economy. 
The Federal Deposit Insurance Corporation (FDIC) has applied this definition in studying metro area housing markets. ${ }^{4}$

This brief defines a house price decline as a case in which nominal house prices decrease by more than 5 percent from their peak over multiple quarters. The paper thus draws a distinction between situations in which nominal house prices fall (to any noticeable degree) and situations in which they merely flatten. The brief also refers to the FDIC convention that a housing bust is a case in which nominal house prices are at least 15 percent below their peak level five years after the peak occurs.

\section{Timing and Characteristics of State House Price Cycles}

In the last three years, prices of existing homes in the U.S. have increased 37 percent in nominal terms, representing an annual rate of increase that is 1.9 times their long-term average. In real terms, the increase has been 30 percent. Hence, the period from the second quarter of 2002 to the fourth quarter of 2005 is close to a boom under the definition based on relative nominal price increases, and it just meets the minimum requirements of the FDIC definition. During these three years, 21 states saw singlefamily home prices increase by more than twice their series average, with magnitudes ranging from just over twice the average (in New York) to four times the average (in Nevada). Twenty states saw real appreciation of 30 percent or more in this period, meeting the FDIC definition of a boom.

Between 1979 and 1995, there were 41 state house price booms (in 38 states) using the nominal-price-increase definition (Table 1). The median rise in nominal prices was 29 percent over a three-year period and 62 percent over a five-year period. About one-half of these price run-ups (20) ended in the flattening of house prices. For purposes of these

\footnotetext{
${ }^{4}$ See “U.S. House Prices: Does Bust Always Follow Boom?" February 2005 and update in May 2005. The FDIC deflates the OFHEO index by the CPI less shelter. This paper uses core CPI as the deflator, since the owners' equivalent rent part of the CPI for shelter can be distorted by energy price fluctuations.
} 
calculations, "flat" indicates no downturn at all, a downturn that is almost immediately reversed, or a downturn sustained over multiple quarters but smaller than 5 percent. The other half of the price run-ups (21) ended in a substantial fall in house prices, with a median decrease of almost 14 percent from peak to trough. These declines include some that have been studied extensively: a decline in Texas starting in 1986, five in New England in 1988-89, and one in California in 1990. (The dates for housing cycles in the text and tables refer to house price peaks.)

Using the FDIC definition based on increases in real house prices of at least 30 percent over three years, there were only eight house price booms in total, all of which occurred in the period from the late 1980s to 1990. These episodes include those in five New England states in 1988-89, in California in 1990, and in New Jersey and New York in 1989-90.

Since 1979, there have been 21 state house price declines. In most cases in which house prices fell to any noticeable degree after a run-up, they fell 10 percent or more. The exceptions include the more modest decreases in Nevada, North Dakota, and New Jersey in the 1980s. Only eight episodes meet the FDIC definition of a house price bust-down 15 percent or more from the peak level, measured five years after the peak. ${ }^{5}$

Most of the house price decreases were concentrated in two periods and were connected to factors causing particular state economies to weaken. The first set of sharp price decreases was associated with the near-halving of oil prices between 1980 and 1986, following their surge between 1978 and 1980. Not surprisingly, many of the affected states were in or near the "oil patch." The second period, the late 1980s to early 1990s, involved the northeastern states and California. These state economies were hurt by

5 Two additional episodes meet the FDIC definition of a bust, but do not appear in Table 1 because they were not preceded by abnormally high house price increases. These episodes occurred in South Dakota and West Virginia in the early 1980s. 
defense downsizing and collapsing commercial real estate markets, in addition to feeling the impacts of the 1990-91 national recession.

\section{Leading Indicators of House Price Peaks: Sales Volumes, Home Construction, and Mortgage Delinquencies}

Although the flattening or falling of prices is widely used as an indication of weakness, prices have rarely proved to be the first sign of turning points in state housing markets. As shown in this section, falling sales of existing homes, falling new home construction, and rising mortgage delinquencies have provided advance warning that house prices were likely to stop increasing. The timing has varied widely across states and time periods. In the typical case, house prices attained their peak about six to eight quarters later. If this median lead-lag relationship were to hold in the current context, the national OFHEO house price index would keep increasing well into 2007.

\section{Existing home sales}

Drawing heavily on evidence from the late 1980s, Karl Case and Robert Shiller have concluded that boom markets are driven "largely by expectations....People seem to form their expectations on the basis of past price movements rather than any knowledge of fundamentals. This increases the likelihood that price booms will persist as home buyers

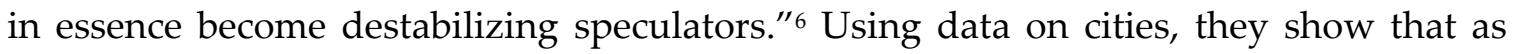
markets begin to weaken, sellers are slow to reduce prices, causing time-on-the-market to increase and the number of sales transactions to decrease.

The state data confirm that sales of existing homes almost always start to decrease while house prices are still on the rise (Table 2). In the FDIC-identified house price booms,

\footnotetext{
${ }^{6}$ Page 45 in Case and Shiller, "The behavior of home buyers in boom and post-boom markets," New England Economic Review, November/December, 1988, pp. 29-46. For a more technical discussion, see Case and Shiller, "The Efficiency of the Market for Single-Family Homes," American Economic Review, vol. 79, no. 1 (March 1989), pp. 125-137.
} 
sales volumes peaked considerably before house prices peaked. In eight cases (all but California in 1990), sales volumes turned down six to 13 quarters ahead of house prices. The median lag between the sales volume peak and the house price peak in FDIC booms was seven months.

A similar pattern was seen in the home price run-ups of the late 1970s and early 1980ssales volumes usually provided a 6-to-12-quarter advance signal of the house price peak. The oil-patch episodes of the mid-1980s were an exception, as existing home sales volumes stopped rising five or more years before the house price peak.

\section{Housing starts}

Since new homes and existing homes are substitutes, any emerging weakness in the market for existing homes is likely to spill over into the expected prices of new homes (and vice versa). As homebuilders see this "writing on the wall," they are likely to curtail new construction. Table 2 confirms that homebuilding activity was a leading indicator of a house price peak in almost every state boom.

In some cases, homebuilder activity provided a much better signal that house prices would stop rising than existing home sales did. For example, during the oil-patch housing booms of the mid-1980s, new home starts in Texas peaked eight quarters ahead of existing home prices. For the California housing boom that ended in 1990, the lead time was seven quarters. In other cases, however, housing starts and housing sales both proved to be valid leading indicators, with one indicator or the other turning down first.

\section{Credit market signals}

Some house price booms ended because buyers came to realize that asking prices were not justified by economic fundamentals. In other cases, the cause was a deterioration in economic fundamentals or some combination of changing expectations and fundamentals. Housing market observers tend to look to credit markets for initial signs 
that economic fundamentals are deteriorating. ${ }^{7}$ While both 30- and 60-day mortgage delinquencies are very noisy, providing real-time evidence that is hard to interpret, 90day mortgage delinquencies are more reliable.

The state data confirm that a pickup in 90-day mortgage delinquency rates for 1-to-4unit residences is usually a precursor to the peaking of house prices (Table 2). In the cases of most of the New England states in the late 1980s to 1990, mortgage delinquencies reached their lows between three and nine quarters before the house price peak. In the cases of Connecticut and California, mortgage delinquency troughs and home price peaks occurred at the same time. For the housing cycles of the late 1970s to the early 1980s, the lead was generally between four and 10 quarters. Once again, the oil-patch housing cycles of the 1980s seem different from the others: mortgage delinquencies turned up too far in advance of the house price peaks to provide a meaningful advance warning signal.

\section{Application to current analysis}

Looking at the current data for the nation, sales of existing homes peaked in the third quarter of 2005, and single-family housing starts peaked in the first quarter of 2006 (Figure 3). Ninety-day mortgage delinquency rates reached their low in the third quarter of 2005, but the interpretation of this turning point is somewhat ambiguous. The increase in delinquencies in late 2005 was mostly the consequence of hurricane-related property damage in the Gulf area. ${ }^{8}$ Outside the South, mortgage delinquency rates were essentially flat in late 2005. In the Northeast, delinquency rates have remained below

\footnotetext{
7 See, for example, Barbara A. Ryan, Associate Director, Division of Insurance and Research, Federal Deposit Insurance Corporation, presentation to The Boston Economic Club, January 25, 2006, for an example using California data.

${ }^{8}$ In this case, the decreases in the supply of housing in the hurricane-affected areas have contributed to a rise in home prices. See the testimony of Patrick Lawler, chief economist of OFHEO before the Committee on Senate Banking, Housing and Urban Affairs subcommittee on economic policy, September 13, 2006.
} 
their 2002 peak levels despite a small uptick in early 2006. In the Midwest, delinquency rates rose sharply in 2002 and have continued to increase.

The history of state housing cycles confirms that sales volumes, construction volumes, and mortgage delinquencies provide advance signals that a house price boom is approaching an end. The timing has varied widely across states and time periods. In the median case, house prices continued to increase for another six to eight quarters before reaching their cyclical peak. This evidence suggests that, on a nationwide basis, average house prices - at least as measured by OFHEO-may continue rising through the end of 2006, and even through the first half of 2007.

It is worth keeping in mind, however, that the OFHEO indexes may remain on course somewhat longer than actual sales transactions prices. This is because the OFHEO data are derived in part from mortgage refinancings (which may reflect somewhat outdated appraisals), and because, in a weakening market, home sellers tend to offer concessions that are not reflected in selling prices. In addition, the OFHEO indexes refer only to mortgages that conform to the underwriting standards of Fannie Mae and Freddie Mac and are not in excess of the conforming loan limit for single-family homes $(\$ 417,000$ in 2006). Thus, the OFHEO series would not promptly pick up turning points concentrated at the high and low ends of the housing market. These transactions are financed by cash or by jumbo or subsidized mortgages to a greater extent than transactions in the middle price range. The indexes also do not cover housing units in multi-unit buildings, such as condominiums.

Another issue is that the lead-lag relationships may have changed from those observed in the past. In particular, innovations in the mortgage market such as variable rates and payment schedules, as well as low down payments, may possibly have changed how quickly house prices change course, relative to the traditional leading indicators. 


\section{Leading Indicators of House Price Stagnation versus Decline}

State histories indicate that the magnitude of a house price boom is not a particularly reliable indicator of whether or not prices are likely to fall when the boom ends. As shown at the bottom of Table 1, the median house price increase in the three years leading up to the peak was virtually the same in the 21 cases where house prices fell as in the 20 cases where house prices flattened (30 percent and 29 percent, respectively). Only when measured over a longer-period - five years-did house prices advance more (78 percent) when they preceded a decrease than when they preceded a flattening (58 percent).

In the absence of a state economic downturn, house prices were more likely to remain flat than to fall in the aftermath of a boom (Table 3). For the 41 booms shown, 25 were not associated with subsequent recessions, judging by the state coincident economic activity indexes developed at the Federal Reserve Bank of Philadelphia. In 18 of these non-recession situations, house prices stopped increasing but did not fall perceptively (at least 5 percent, over multiple quarters). The seven cases in which house prices fell in the absence of a state recession involved fairly small states.

When states experienced a recession, house price run-ups were almost always followed by a period of decreasing prices. This was the situation in the New England states and California in 1989-90. The only exceptions were Maryland and New York in 1990.9

Nevertheless, judging by their timing, state recessions were usually triggered by factors other than falling house prices. In 10 of the 15 cases of falling house prices, house prices did not drop until after an economic downturn had started. The exceptions include Alaska in 1984, Connecticut in 1988, and New Jersey in 1989, where house prices started

\footnotetext{
${ }^{9}$ The OFHEO index for New York dipped slightly in this period, but not enough to meet the 5-percent threshold used in this brief to mark a fall in state home prices.
} 
decreasing between one and three quarters prior to the downturns in the state economy, as determined by the Philadelphia Fed coincident indexes. In the remaining two cases, the drop in home prices and the onset of the recession were contemporaneous. On the whole, this evidence from state housing cycles suggests either that house prices fell in response to recession, or that other disruptions to the economy caused both house prices and economic activity to turn down. ${ }^{10}$

In summary, a sharp appreciation in home values is sometimes-but not alwaysfollowed by a large decrease. Decreases in home values are more likely when additional factors depress the housing market. When this happens, it is likely that the economy has turned down shortly before house prices have reached their peak.

\section{Modeling House Price Drops Using Metropolitan Area Data}

This section uses insights from examining house prices by state to estimate an empirical model of house price declines by metropolitan area. In this model, the probability of a house price decline depends on both the degree of existing overvaluation of housing and on changes in economic fundamentals that affect housing. The brief draws from two recent research efforts from outside the Federal Reserve System, both of which use OFHEO indexes for metropolitan areas, to provide numerical input for the model. This section provides details on methodology and historical goodness-of-fit and shows how the findings can provide lessons for interpreting the U.S. housing data in the aggregate.

\section{What is overvaluation?}

Two very different methods have been used recently to provide evidence on housing market overvaluation. One approach is to start by assuming that, on average, houses are neither overvalued nor undervalued over a long stretch of time, and then to fit a model

10 More formal econometric studies using country data have reached mixed conclusions on whether drops in house prices cause recessions or recessions cause drops in house prices. 
to explain past movements in house prices based on some posited economic fundamentals. Specific variables are chosen from among plausible candidates so as to provide a good fit. These variables typically include personal income and mortgage interest rates as indicators of the demand for housing, as well as measures of building costs or constraints as measures of supply-side factors. In any given period, housing is characterized as overvalued or undervalued by comparing actual prices to expected prices based on the posited fundamentals. If housing is found to be overvalued over a sufficiently long interval, the presumption is that house prices will decline, or that economic fundamentals will improve, eliminating the overvaluation.

National City and Global Insight have collaborated in implementing such an approach, estimating the historical relationship between house-price-to-income ratios and a set of determinants that include the 30-year fixed mortgage rate and metropolitan-area characteristics (see Box 1). Extending the results to the current period, they found that house prices had increased sufficiently in many metropolitan markets to exceed significantly the values justified by the usual explanatory factors. Specifically, housing was overvalued in 135 out of 299 metro areas in the fourth quarter of 2005. ${ }^{11}$

An alternative approach evaluates prices relative to those derived by calculating the annualized cost of homeownership. This methodology recognizes that housing is an asset that provides both shelter and investment returns over time. Equilibrium prices are derived by assuming that market participants make immediate and full use of the available information on the returns to homeownership versus the alternative of renting a housing unit and investing in other assets. This framework is used to determine the

\footnotetext{
${ }^{11}$ See "House Prices in America: Valuation Methodology and Findings," July 2005, updated in December 2005, and "House Prices in America: Methodology Update," June 2006, available at www.nationalcity.com/corporate/EconomicInsight. Our thanks to principal author Richard DeKaser for sharing otherwise unavailable details and additional perspectives. The National City house price analysis has since been expanded to include an additional 18 metropolitan areas. The sample expansion is not taken into account in this brief, but is unlikely to change the results substantially.
} 
extent to which home prices exceed or fall short of their equilibrium value, given rents and other relevant economic fundamentals and taking into account the relationship among these variables in a historical sample period. Overvaluation (relative to equilibrium) may signal that house prices are based on flawed information, such as inflated estimates of the returns to homeownership. A differential between actual and equilibrium prices may also indicate that housing market participants are taking into account factors that cannot be readily justified within the standard economic model.

The study by Himmelberg, Mayer, and Sinai exemplifies this second approach (see Box 2). They used an explicit model to compute the annualized cost of homeownership relative to rents in 47 large metropolitan areas. They argued that, as of late 2005, house prices in these cities were not particularly out of line with equilibrium values. In their analysis, house price increases through 2005 were driven largely by economic fundamentals-especially the reduction in interest rates to low levels-rather than by unreasonable forecasts of capital gains. ${ }^{12}$

\section{Modeling fundamental and non-fundamental determinants of house prices}

This paper uses the measures of economic fundamentals and non-fundamentals from these two studies to model the probability of declining house prices. ${ }^{13}$ Specifically, the measure of fundamentals derived from the National City/Global Insight analysis consists of the portion of the house-price-to-income ratio that can be explained by mortgage interest rates, metro area income relative to national income, metro area housing density, and metro-specific constants. On the basis of the Himmelberg-Mayer-

\footnotetext{
${ }^{12}$ See "Assessing High House Prices: Bubbles, Fundamentals and Misperceptions," The Journal of Economic Perspectives, Fall 2005, pp. 67-92, as updated at

www2.gsb.columbia.edu/departments/realestate/pubs/publications.html. Thanks to Christopher Mayer and research assistant Steven Kleiman for providing additional unpublished data and insights.

${ }_{13}$ This specification is different from assuming that overvaluation alone can explain subsequent price declines. See Box 3 for historical evidence on the correlation between the degree of overvaluation and the extent of price correction.
} 
Sinai study, fundamentals are derived from the ratio of the annualized cost of homeownership ("imputed rent") to actual rent.

The model takes the following form:

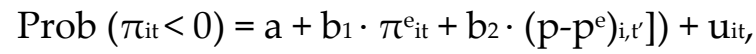

where

$$
\begin{aligned}
\pi= & \text { percent change in house prices } \\
\pi^{\mathrm{e}}= & \text { percent change in expected price based on National City/ Global Insight } \\
& \text { study or percent change in equilibrium price based on Himmelberg- } \\
& \text { Mayer-Sinai study } \\
p^{-} p^{e}= & \text { percent difference between actual and expected or equilibrium price } \\
\mathrm{u}= & \text { model error } \\
\mathrm{i}= & \text { metro area } \\
\mathrm{t}= & \text { time period } \\
\mathrm{t}^{\prime}= & \text { lagged time period }
\end{aligned}
$$

The term on the left-hand side of the equals sign represents the probability that home prices decline on a fourth-quarter-over-fourth-quarter basis. The first term on the righthand side denotes the percent change in home prices over this same period that is justified on the basis of changing fundamentals, as modeled in the two studies considered. The last term represents the degree of overvaluation and is measured as the percent difference between actual and expected prices (or between actual and equilibrium prices) 12 quarters earlier. For example, the overvaluation measure for the fourth quarter of 2003 is used to explain the four-quarter price change in the period ending in the fourth quarter of 2006. ${ }^{14}$ The model was estimated using OFHEO home

\footnotetext{
${ }^{14}$ A lag of 12 quarters provided a better fit than a lag of four or eight quarters.
} 
price indexes for all metro areas experiencing at least one fourth-quarter-over-fourthquarter decrease over the period for which its overvaluation measures were available. ${ }^{15}$

For the version using the National City / Global Insight figures on fundamentals and overvaluation, the model was estimated for the 183 areas that had experienced at least one price decline, based on data from 1985 through 2005. For the Himmelberg-MayerSinai version, there were 47 metro areas and the estimation period was 1980 to 2005. The regressions were estimated using "fixed effects." Essentially, this method allows each area's price movements, fundamentals, and overvaluation to be adjusted for whatever is typical for the particular area over the sample period.

\section{Mixed success in accounting for past home price movements}

As expected, the regressions show that an improvement in market fundamentals leads to a lower probability of a house price decline, while greater overvaluation relative to expected or equilibrium values leads to a higher probability of a house price decline within two to three years. However, neither the National City/Global Insight nor the Himmelberg-Mayer-Sinai specification provided high explanatory power for specific metropolitan area and year combinations during the historical sample period. ${ }^{16}$ This is not surprising, given the erratic behavior of house prices at the city level.

\footnotetext{
${ }^{15}$ Because the dependent variable is dichotomous (that is, prices are observed either to fall or not fall), probit regression was used in estimating the model.

${ }^{16}$ For each set of estimates, we chose a threshold probability that allowed the regression to measure correctly the overall number of instances of price decrease in the full time period. If the model's estimate was greater than or equal to this threshold probability, this was interpreted as a "decrease." For example, using the data from National City / Global Insight, the threshold probability was 0.116 . Even calibrating the model to estimate correctly that there were 459 instances of price decrease between 1988 and 2005, it identified only 204 of them. Among these were Boston in 1989 and 1990, Los Angeles in 1992-1994, New York in 1989-1991, and San Francisco in 1991-1993. In 255 other cases, it estimated that prices would decrease in a particular metro area, whereas prices actually held steady or increased. By construction, the model also missed 255 cases of actual price decrease, including Boston in 1991, 1992, and 1994, Los Angeles in 1991, 1992, and 1996, New York in 1994, and San Francisco in 1990 and 1994.
} 
For macroeconomic purposes, it is less important to model which particular markets see house price decreases than to model the overall pervasiveness of price decreases. Accordingly, the next step was to examine the model's estimates of how many metro areas would experience price decreases each year.

The results are shown in Figure 4 and can best be described as "mixed." Based on the National City/Global Insight data (top panel), the model correctly estimates that price decreases should have been more common in the period 1988-94 than during 1997-2004. Its estimates for 12 of the 18 years are reasonably accurate: 1990-93, 1995, 1997-98, and 2000-04. On the other hand, the model cannot account for the very high number of price declines in 1994 and 1996, and it also underestimates in 1999. The model far overestimates in 1988 and 1989. Moreover, the model anticipates 41 decreases in 2005, versus the two that actually occurred.

The aggregated model estimates using inputs from the Himmelberg-Mayer-Sinai study are shown in the lower panel of Figure 4. In 1983 and 1987, the model was too pessimistic, expecting a very large share of the metro areas in the sample to have had price declines, when, in fact, actual conditions were much more favorable. In recent years, however, the model has been very accurate using data drawn from HimmelbergMayer-Sinai. It correctly indicates that there should have been very few declines since 1995.

\section{Simulations for 2006 and 2007}

Next, the metro area model was simulated for 2006 and 2007, with the intent to derive the implied direction of change in the national OFHEO index. This required making certain important assumptions, since future changes in economic fundamentals are uncertain. 
The simulations with the fundamentals from National City/Global Insight assume personal income growth of 5 percent per year in 2006 and 2007, a mortgage rate increase of 75 basis points from the fourth quarter of 2005 to the fourth quarter of 2006, and unchanged mortgage rates in 2007. We also simulate a 50-basis-point increase in mortgage rates in 2007, to provide a sense of the range of possible outcomes, as assumptions vary. To extrapolate using the Himmelberg-Mayer-Sinai definitions, the exercise assumes that apartment rents will be flat through the end of 2007, while mortgage rates increase by 75 basis points from the fourth quarter of 2005 to the fourth quarter of 2006, and then remain flat in 2007. Again, we also consider the implications of an interest rate increase of 50 basis points in $2007 .{ }^{17}$

No assumptions on the degree of overvaluation were needed for the simulations. According to the lags built into the model, the anticipated house price movements between the fourth quarter of 2005 and the fourth quarter of 2006 are based on end-of2003 overvaluation, and the fourth-quarter-of-2006-to-fourth-quarter-of-2007 predictions use the end-of-2004 overvaluation.

Despite their differences, both approaches to defining market fundamentals lead to a prediction that some metropolitan areas will have house price declines in 2006 and 2007. In the case of the National City approach, the results are driven by their finding of extensive overvaluation at year's end in 2003, and even more pervasive overvaluation at year's end in 2004. Using the Himmelberg-Mayer-Sinai methodology, the results are due primarily to their finding that equilibrium house prices are highly sensitive to interest

\footnotetext{
${ }^{17}$ The assumptions on mortgage interest rates are not intended to be a prediction, but are roughly consistent with the consensus expectations of private-sector forecasters. The choice of 50 basis points to represent an increase in mortgage rates is also intended only for illustration, and represents neither a prediction nor a plausible upper bound.
} 
rates. Hence, the assumed rise in interest rates in the projection period is the major driver. ${ }^{18}$

Simulating the model using the National City data, there are 51 (out of 183) metropolitan areas with price declines in 2006, and 63 in 2007. In the case of the interest rate increase in 2007, there are 64 predicted declines. Using the Himmelberg-Mayer-Sinai data yields 19 declines (out of 47) in 2006 and 8 declines in 2007. Assuming a 50-basis-point increase in mortgage rates implies 17 declines in 2007. In both cases, and under both assumptions for 2007, there would be more metro areas with falling house prices than in any year since 1994. (In that year, there were 93 decreases using the sample of 183 areas, and 21 decreases using the sample of 47 areas).

In order to make inferences about national home price movements in 2006 and 2007, Figure 5 graphs the four-quarter percent change in the national OFHEO index against the number of metro areas (out of 183) with a house price decrease in each year between 1988 and 2005. Not surprisingly, during years when more cities experienced decreasing home prices, the rate of appreciation in national home prices tended to be lower. ${ }^{19}$

The downward-sloping line in Figure 5 indicates the "best fit," given the historical data on the U.S. and metro areas. For some years (such as 1990 and 2003), low U.S. house price appreciation can be "explained" simply on the basis of how many cities experienced decreases. For other years, the national OFHEO index increased more (for example, in 2005) or less (for example, in 1992), than the "best fit" relationship between these data would indicate. Such discrepancies are a sign that the average rates of metro area price increases and decreases were unusual in these years, relative to historical norms. For example, simply looking at the number of cities with falling prices might

\footnotetext{
${ }_{18}$ Also, the assumption on rents imposes the restriction that any changes in overvaluation would be achieved entirely through a change in prices (rather than rents).

${ }^{19}$ Weighting cities by their population yields similar results.
} 
provide too high an estimate of the national average in a year when cities with falling home prices had particularly sharp drops.

The extrapolations to 2006 and 2007 are also shown in Figure 5, and are based on the assumption that projections of the number of metro areas with falling house prices provide sufficient information for deriving the national index. ${ }^{20}$ Regardless of whether one adopts the National City or the Himmelberg-Mayer-Sinai approach to analyzing housing prices, the exercise yields a considerable slowdown in house price appreciation to roughly 1 to 3 percent in 2006. Since the OFHEO index rose 3.4 percent between the fourth quarter of 2005 and the second quarter of 2006, the 2006 extrapolation implies that U.S. house prices will be approximately flat or declining slightly in the second half of 2006.

The 2007 results also point to modest appreciation. Assuming mortgage interest rates remain flat, the extrapolation using the National City framework shows house price growth slowing to 2 percent in 2007. By contrast, the simulation based on the Himmelberg-Mayer-Sinai study implies 5-percent appreciation in home prices in 2007. On the assumption that mortgage interest rates rise by 50 basis points, the OFHEO home price index increases slightly less than 2 percent in 2007 under both frameworks.

\section{Conclusions}

This brief has demonstrated that, at least for states, house prices typically continue to increase even after other housing market indicators such as sales, construction, and mortgage delinquencies deteriorate. This finding is relevant in interpreting incoming national data showing weakening housing markets.

\footnotetext{
${ }^{20}$ For the purpose of deriving 2006 and 2007 values in Figure 5, the number of declines from the Himmelberg-Mayer-Sinai exercise was scaled up in each year, based on having 183 rather than 47 cities in the sample.
} 
Using data on cities, the brief documents that house price declines can be explained to some extent by changes in economic fundamentals and the preexisting degree of overvaluation of housing. Also, the more cities with declining house prices, the lower the appreciation in aggregate U.S. house prices tends to be. An extrapolation exercise using these findings-together with the assumptions of continued personal income growth and little if any further increases in mortgage interest rates-indicates that appreciation in U.S. home prices in 2006-07 is likely to be modest. However, in identifying past misses, the analysis demonstrates the inherent risks in trying to project home prices.

The brief does not attempt to estimate the effect of innovations in mortgage markets. These structural changes could affect both the duration of continued house price increases and the probability of their decline. 


\section{Box 1}

\section{National City/Global Insight Approach to Determining Overvaluation}

The National City/Global Insight study analyzes house-price-to-income ratios for 299 metropolitan areas that accounted for 80 percent of the value of U.S. market. Starting in the first quarter of 2006, 317 metropolitan areas are considered, representing 85 percent of the total market. The study assumes that house prices during the 1981-2005 period maintain a "normal" relationship to underlying factors. To that end, the study regresses metro area house-price-to-income ratios on the 30-year fixed mortgage interest rate (converted to an annuity equivalent), each area's income relative to the national average, each area's number of households per square mile (a proxy for land scarcity), and a metro area constant term. This regression determines the relationship between house prices and the underlying factors over the period. The relationship is then used to estimate what house prices "should" be in a given quarter, according to the model. If this estimate is lower than the actual price in the metro area, house prices are higher than the underlying factors indicate they should be and are thus considered to be overvalued in that quarter. In the fourth quarter of 2005, house prices were found to exceed predicted values in more than 200 metro areas, but sometimes only minimally. Based on analyzing variances, National City considers only 135 areas to be overvalued, meaning that actual prices were at least 13 percent higher than predicted. 


\section{Box 2}

\section{The Himmelberg-Mayer-Sinai Approach to Analyzing House Prices}

Himmelberg, Mayer, and Sinai (HMS) employ the user cost of capital concept to analyze house prices in 47 major metropolitan areas. Their approach compares the annualized cost of homeownership (also called the "imputed rent") to the annual rental cost for a similar property. The annualized cost of homeownership consists of the forgone interest that the homeowner could have earned by investing in another asset of comparable risk plus the maintenance costs and property taxes on the house, all net of any applicable income taxes. Offsetting these costs is the accrued capital gain on the house. In equilibrium, the imputed rent from the home equals the annual cost of renting.

The study computes imputed rents and actual rents annually for the period 1980 to 2005 , using data and assumptions that vary across metro areas, as appropriate. The authors build in "reasonable" assumptions on capital gains from housing, rather than using the capital gains that homeowners (perhaps mistakenly) expected at any given time, based on recent experience. Lacking information on rental rates for units comparable to single-family homes, HMS rely on representative rates for twobedroom apartments, in an attempt to hold the quality of the comparison rental unit constant over time. If the ratio of the actual observed rents to the imputed rents for a metropolitan area is greater than one, then house prices exceed their equilibrium values, at least relative to the usual patterns observed in the area. If such a situation persists, market forces exert greater downward pressure on house prices, compared with the situation in which house prices equal their equilibrium values. 


\section{Box 3}

\section{Housing Overvaluation vs. House Price Correction}

Regardless of which study one uses to analyze housing markets, the measure of overvaluation cannot be expected to determine the extent of subsequent house price correction. This fact is well understood by housing market specialists, but is sometimes overlooked in popular discussions. This box uses historical data to illustrate the correlation between the degree of housing overvaluation and the extent of subsequent house price decline.

Consider the National City/ Global Insight measures of overvaluation during the 1980s and early 1990s in the chart below. (Similar patterns hold for the HMS study.)

The top panel displays the maximum overvaluation reached by a severely overvalued (overvaluation of 30 percent or more during 1985-1989) metropolitan area, plotted against its subsequent decline. All of the 49 severely overvalued areas did, in fact, experience a price decline, but the decline usually was considerably less than the maximum extent of overvaluation. Boston, for example, reached a maximum overvaluation of 34 percent in the first quarter of 1987, but prices fell by "only" 12 percent from the price peak in 1988 to the subsequent trough in 1992. The same is largely true for the other severely overvalued metro areas in this period, as the vast majority lie to the left of the 45-degree line, which denotes a house price decline equal to the maximum overvaluation. In general, price declines do not account for all of a price correction, as fundamentals may improve over the duration of the decline.

The lower panel displays the overvaluation percentage at the price peak, plotted against the subsequent price decline. (This panel omits 17 metro areas that experienced a price peak prior to 1985, before the overvaluation measure was available). Again, most metro areas experienced a house price decline that was less than the overvaluation at the price peak, where the price peak is defined as the quarter immediately prior to the decline. 


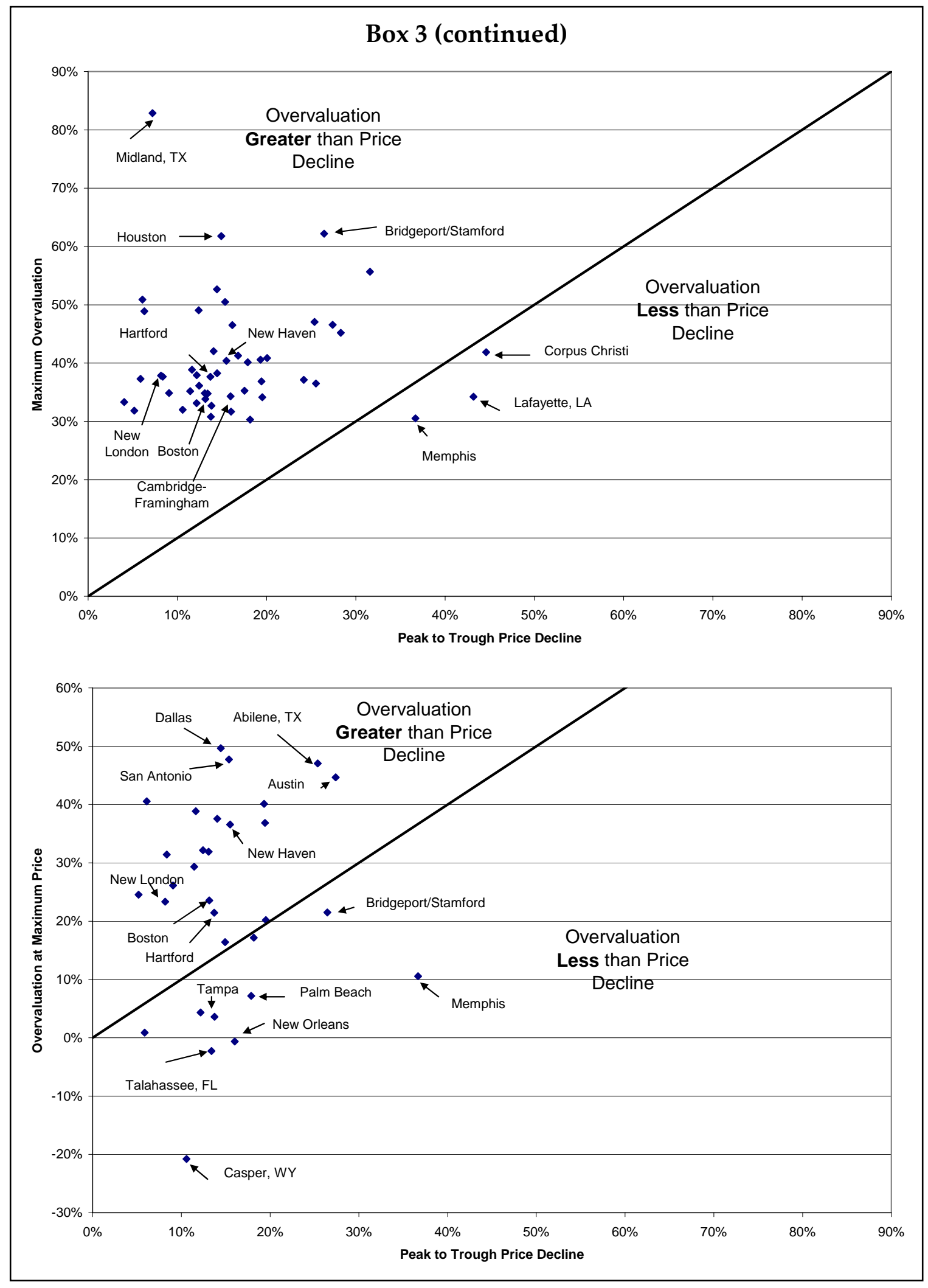


Figure 1: OFHEO Home Price Index United States, 1976 - 2006

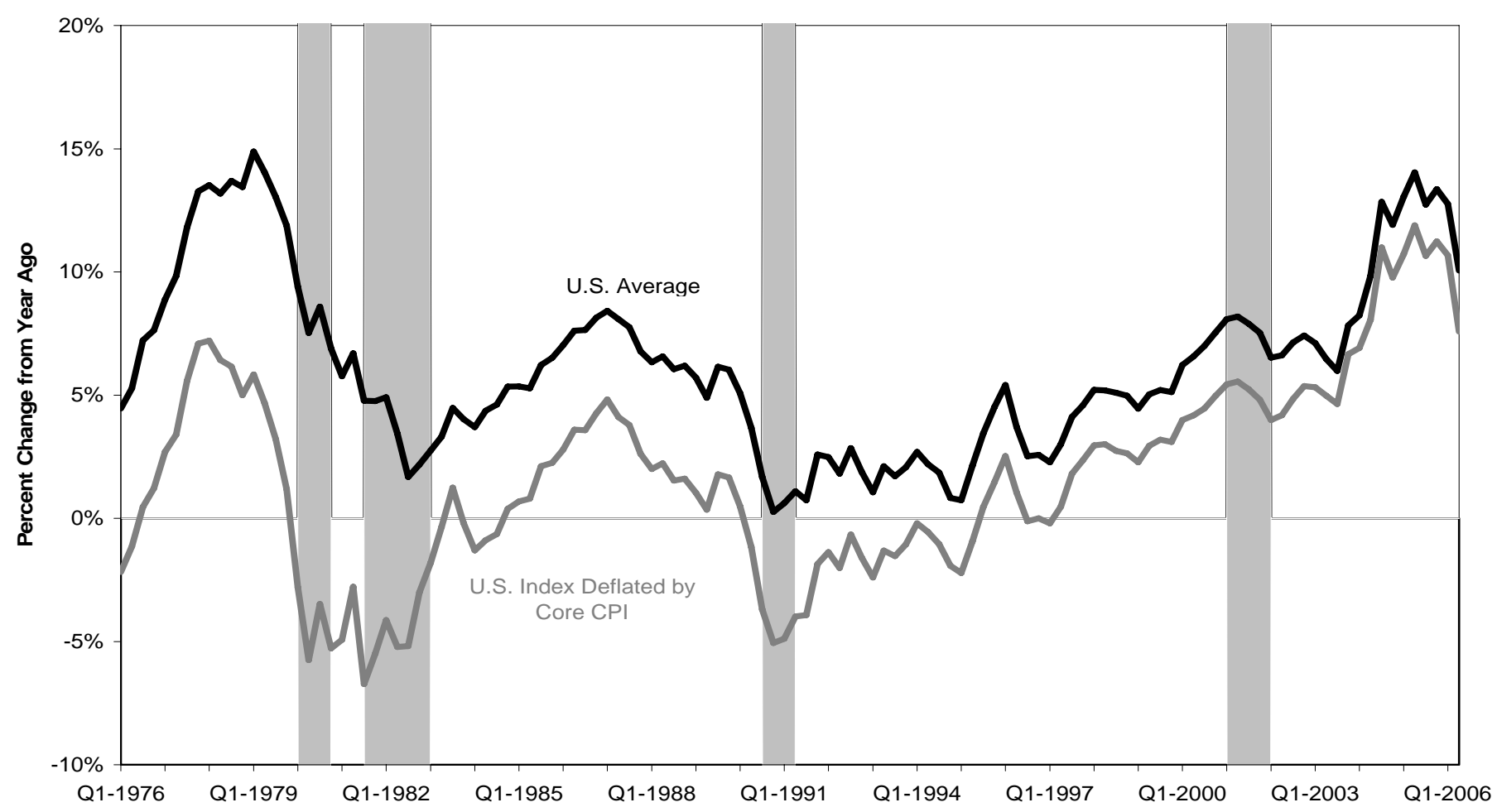

Source: OFHEO and Bureau of Labor Statistics

Figure 2: OFHEO Home Price Index for Selected Cities 1979 - 2006,

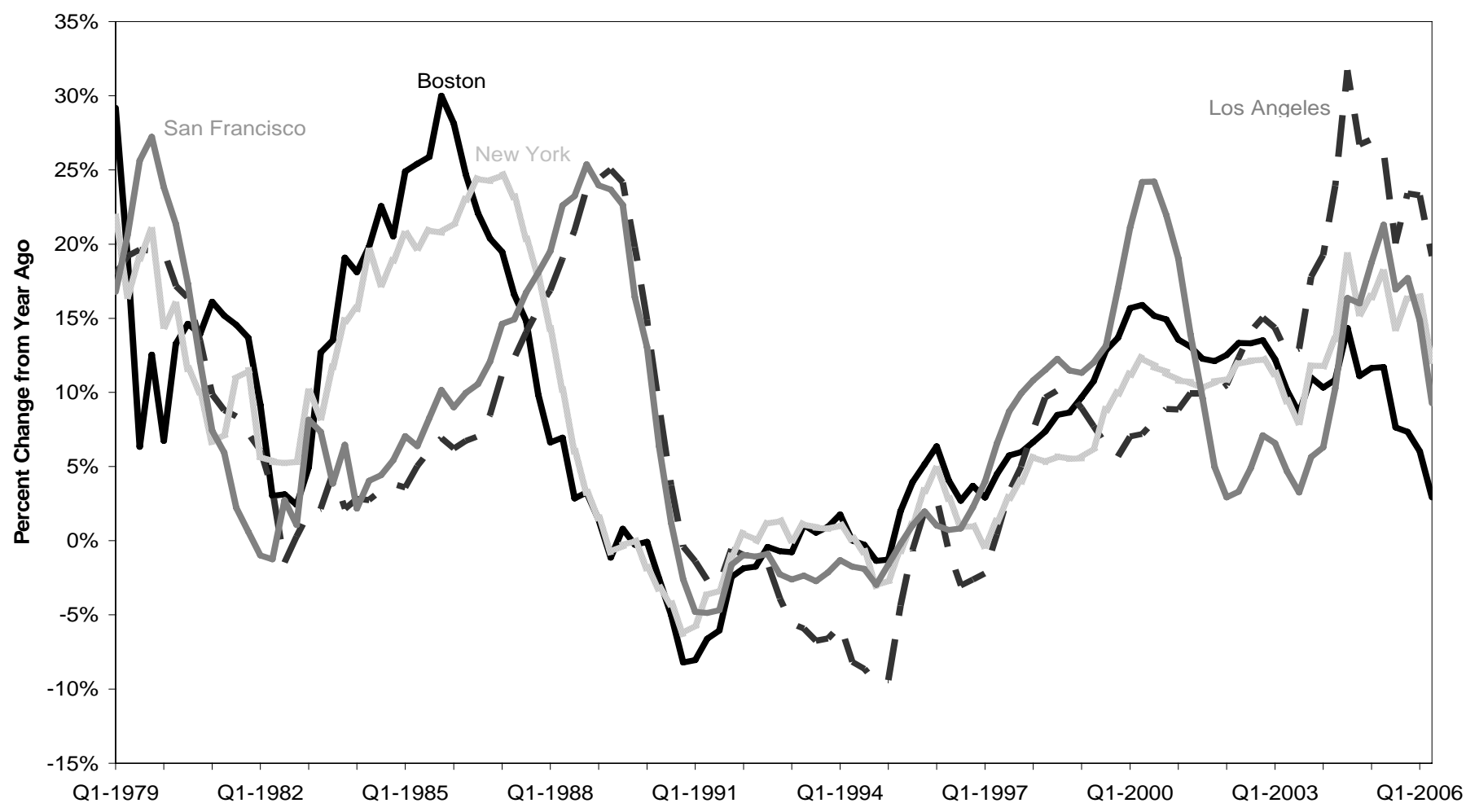

Source: OFHEO. 
Figure 3

\section{National Housing Market Indicators}

Total Existing Home Sales
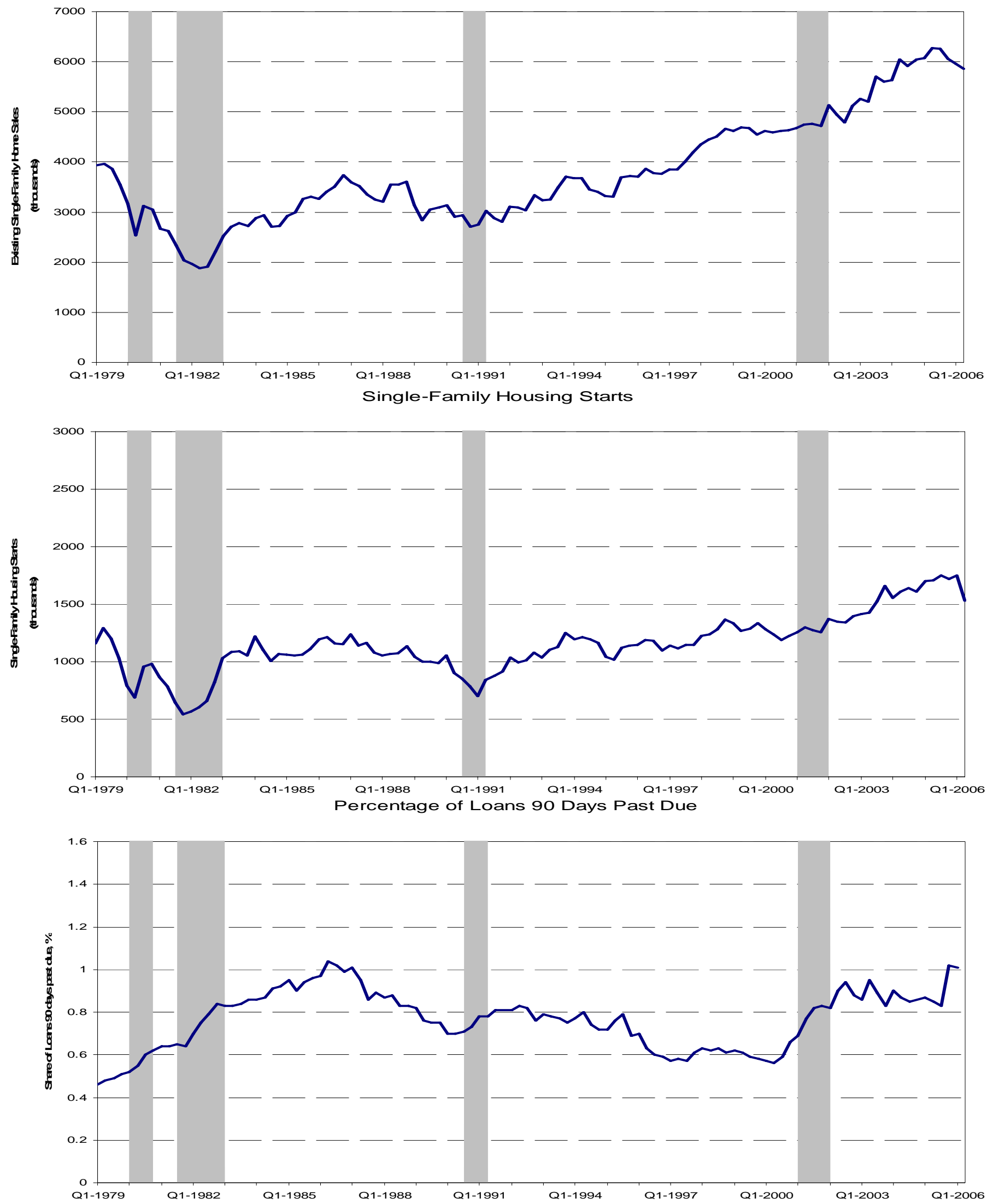

Source: National Association of Realtors, Mortgage Bankers Association, and Bureau of the Census. 
Figure 4

Number of Metropolitan Areas with a House Price Decline, 1988 to 2005, and Extrapolations for 2006 and 2007
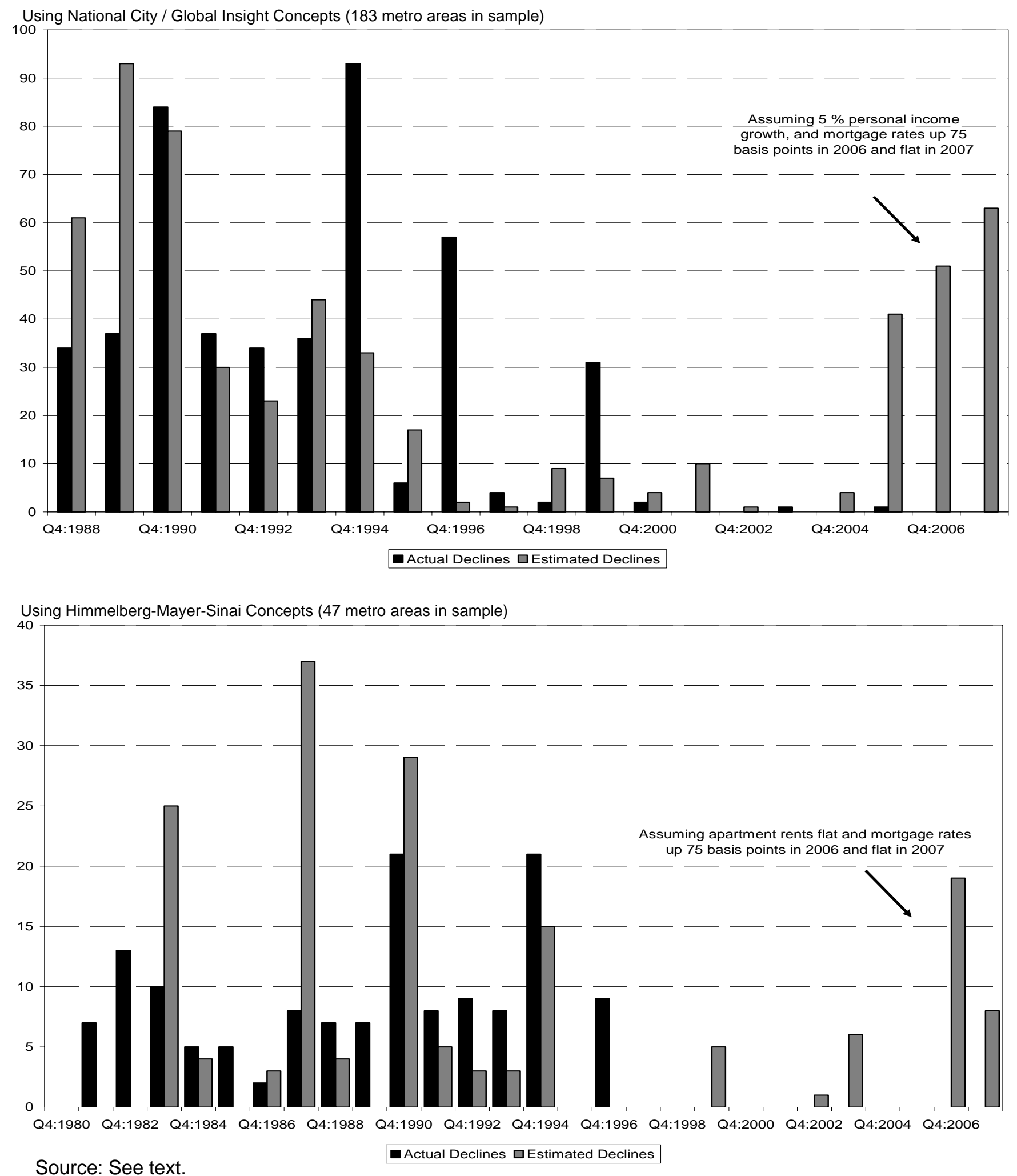
Figure 5

Relationship Between Number of Metropolitan Areas with a House Price Decline and Percent Change in U.S. House Prices,

1988 to 2005, with Extrapolations for 2006 and 2007

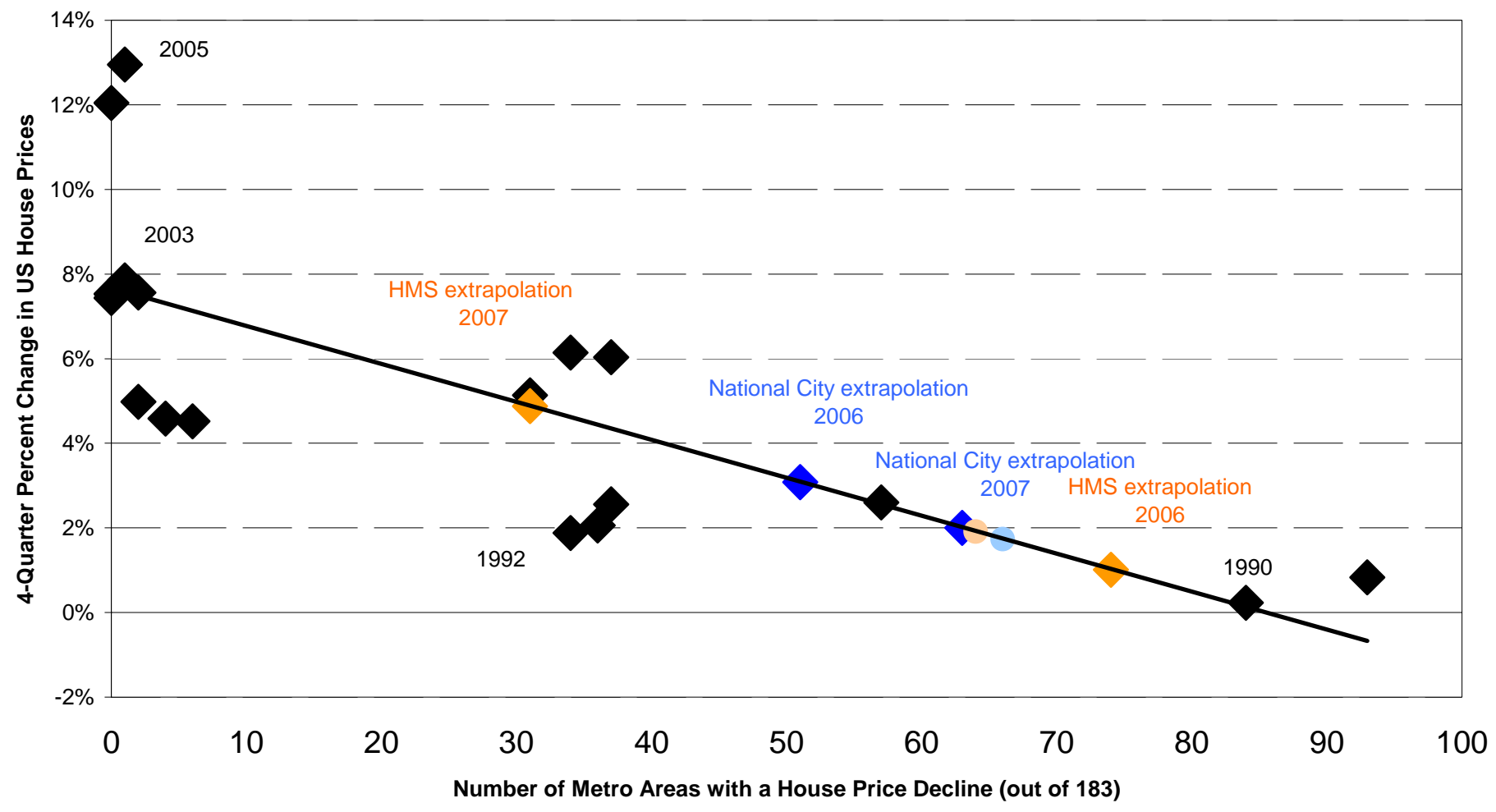

Note: Extrapolations for 2007 using a 50 basis point increase in mortgage rates are plotted as circles.

Source: See text. 


\section{Table 1: State House Price Booms, 1979 - 1995}

\begin{tabular}{|c|c|c|c|c|c|c|}
\hline State & House price peak & $\begin{array}{l}\text { Price increase from } 3 \\
\text { years before peak }\end{array}$ & $\begin{array}{l}\text { Price increase from } 5 \\
\text { years before peak }\end{array}$ & $\begin{array}{l}\text { House price } \\
\text { trough }\end{array}$ & $\begin{array}{l}\text { Price decrease, } \\
\text { peak to trough }\end{array}$ & FDIC bust? \\
\hline ID & Q4-1979 & $9.2 \%$ & $46.3 \%$ & & & \\
\hline $\mathrm{OH}$ & Q4-1979 & $37.0 \%$ & & & & \\
\hline IN & Q1-1980 & $36.7 \%$ & $58.6 \%$ & & & \\
\hline MO & Q2-1980 & $37.8 \%$ & $53.2 \%$ & & & \\
\hline WV & Q2-1980 & $60.8 \%$ & $77.6 \%$ & & & \\
\hline IA & Q3-1980 & $25.9 \%$ & $54.7 \%$ & Q3-1981 & $-9.9 \%$ & no \\
\hline OR & Q3-1980 & $45.8 \%$ & $102.9 \%$ & Q3-1984 & $-9.9 \%$ & no \\
\hline WI & Q3-1980 & $32.8 \%$ & $70.0 \%$ & & & \\
\hline KS & Q4-1980 & $29.3 \%$ & $61.4 \%$ & & & \\
\hline NE & Q4-1980 & $34.5 \%$ & $58.4 \%$ & & & \\
\hline VT & Q4-1980 & $30.6 \%$ & $68.6 \%$ & Q4-1981 & $-13.7 \%$ & no \\
\hline DC & Q2-1981 & $40.6 \%$ & $105.7 \%$ & Q3-1982 & $-17.2 \%$ & no \\
\hline CA & Q4-1981 & $45.1 \%$ & $114.5 \%$ & & & \\
\hline MI & Q4-1981 & $23.3 \%$ & $63.1 \%$ & Q4-1983 & $-11.3 \%$ & no \\
\hline NV & Q1-1982 & $30.6 \%$ & $87.2 \%$ & Q3-1984 & $-7.0 \%$ & no \\
\hline WA & Q1-1982 & $23.7 \%$ & $87.5 \%$ & & & \\
\hline NM & Q3-1982 & $38.8 \%$ & $75.7 \%$ & & & \\
\hline WY & Q4-1982 & $18.9 \%$ & $57.6 \%$ & Q1-1989 & $-29.5 \%$ & yes \\
\hline $\mathrm{CO}$ & Q3-1983 & $18.5 \%$ & $48.4 \%$ & & & \\
\hline $\mathrm{HI}$ & Q3-1983 & $8.7 \%$ & $70.0 \%$ & & & \\
\hline OK & Q4-1983 & $23.4 \%$ & $48.0 \%$ & Q3-1988 & $-23.7 \%$ & yes \\
\hline MS & Q1-1984 & $28.4 \%$ & $22.2 \%$ & & & \\
\hline LA & Q2-1984 & $8.7 \%$ & $28.3 \%$ & Q4-1988 & $-15.4 \%$ & yes \\
\hline MT & Q2-1984 & $42.2 \%$ & $102.4 \%$ & Q4-1987 & $-17.5 \%$ & yes \\
\hline AK & Q3-1984 & $24.5 \%$ & $61.8 \%$ & Q1-1990 & $-36.4 \%$ & yes \\
\hline ND & Q3-1985 & $43.3 \%$ & $17.8 \%$ & Q4-1988 & $-7.4 \%$ & no \\
\hline TX & Q2-1986 & $4.8 \%$ & $19.1 \%$ & Q4-1988 & $-13.7 \%$ & no \\
\hline$A Z$ & Q1-1987 & $14.4 \%$ & $23.3 \%$ & & & \\
\hline CT & Q2-1988 & $74.8 \%$ & $124.9 \%$ & Q1-1995 & $-16.8 \%$ & yes \\
\hline $\mathrm{NH}$ & Q1-1989 & $29.8 \%$ & $89.7 \%$ & Q4-1994 & $-19.6 \%$ & yes \\
\hline GA & Q4-1989 & $11.3 \%$ & $26.0 \%$ & & & \\
\hline MA & Q4-1989 & $14.4 \%$ & $77.8 \%$ & Q2-1992 & $-10.9 \%$ & no \\
\hline ME & Q4-1989 & $80.0 \%$ & $100.8 \%$ & Q4-1994 & $-8.7 \%$ & no \\
\hline NJ & Q4-1989 & $25.0 \%$ & $81.8 \%$ & Q4-1991 & $-7.8 \%$ & no \\
\hline RI & Q4-1989 & $41.9 \%$ & $110.8 \%$ & Q4-1994 & $-13.2 \%$ & no \\
\hline VT & Q4-1989 & $39.0 \%$ & $70.3 \%$ & & & \\
\hline NY & Q1-1990 & $17.7 \%$ & $51.1 \%$ & & & \\
\hline VA & Q2-1990 & $27.8 \%$ & $47.2 \%$ & & & \\
\hline CA & Q3-1990 & $51.5 \%$ & $80.0 \%$ & Q1-1995 & $-12.5 \%$ & no \\
\hline MD & Q3-1990 & $28.4 \%$ & $57.1 \%$ & & & \\
\hline $\mathrm{HI}$ & Q3-1994 & $2.7 \%$ & $37.8 \%$ & Q4-1999 & $-15.3 \%$ & yes \\
\hline
\end{tabular}

Median values:

\begin{tabular}{|c|c|c|c|}
\hline All state booms & $29.3 \%$ & $62.4 \%$ & \\
\hline $\begin{array}{l}\text { States with peaks followed } \\
\text { by flat prices }\end{array}$ & $28.9 \%$ & $58.4 \%$ & \\
\hline $\begin{array}{l}\text { States with peaks followed } \\
\text { by falling prices }\end{array}$ & $29.8 \%$ & & $-13.5 \%$ \\
\hline FDIC booms & $40.4 \%$ & $80.9 \%$ & $-11.7 \%$ \\
\hline FDIC busts & $23.9 \%$ & $59.7 \%$ & $-18.5 \%$ \\
\hline
\end{tabular}

Note: Table 1 shows all cases in which the nominal house price increase at an annual rate over a three-year period is greater than twice the state's long-term average. Shaded rows denote cases meeting the FDIC definition of a house price boom. Blanks entries indicate not applicable.

Source: See Figure 3 and text. 


\section{Table 2 : Timing of House Price Peak Relative to Sales, Starts, and Mortgage Delinquencies}

\begin{tabular}{|c|c|c|c|c|c|c|c|c|}
\hline State & House price peak & $\begin{array}{l}\text { House price } \\
\text { trough }\end{array}$ & $\begin{array}{l}\text { Sales of exisiting } \\
\text { units peak }\end{array}$ & $\begin{array}{l}\text { Quarters by which sales } \\
\text { peak led price peak }\end{array}$ & $\begin{array}{l}\text { Housing starts } \\
\text { peak }\end{array}$ & $\begin{array}{l}\text { Quarters by which } \\
\text { starts peak led } \\
\text { price peak }\end{array}$ & $\begin{array}{l}\text { 90-day mortgage } \\
\text { delinquency trough }\end{array}$ & $\begin{array}{l}\text { Quarters by which } \\
\text { delinquency trough } \\
\text { led price peak }\end{array}$ \\
\hline$\overline{I D}$ & Q4-1979 & & Q1-1979 & 3 & Q4-1977 & 8 & & \\
\hline $\mathrm{OH}$ & Q4-1979 & & Q2-1978 & 6 & Q2-1977 & 10 & & \\
\hline IN & Q1-1980 & & Q2-1978 & 7 & Q3-1979 & 2 & & \\
\hline MO & Q2-1980 & & Q2-1978 & 8 & Q1-1978 & 9 & Q1-1979 & 5 \\
\hline WV & Q2-1980 & & Q4-1978 & 6 & & & Q1-1979 & 5 \\
\hline IA & Q3-1980 & Q3-1981 & Q2-1978 & 9 & Q2-1979 & 5 & Q1-1979 & 6 \\
\hline OR & Q3-1980 & Q4-1981 & Q1-1979 & 6 & Q1-1978 & 10 & Q3-1979 & 4 \\
\hline WI & Q3-1980 & & Q2-1978 & 9 & Q2-1977 & 13 & Q2-1979 & 5 \\
\hline KS & Q4-1980 & & Q2-1978 & 10 & Q2-1979 & 6 & & \\
\hline NE & Q4-1980 & & Q2-1978 & 10 & Q4-1978 & 8 & Q4-1981 & -4 \\
\hline VT & Q4-1980 & Q4-1981 & Q4-1980 & 0 & Q2-1979 & 6 & Q1-1980 & 2 \\
\hline DC & Q2-1981 & Q3-1982 & Q4-1986 & -22 & Q3-1980 & 3 & Q2-1981 & 0 \\
\hline CA & Q4-1981 & & Q1-1979 & 11 & Q4-1978 & 12 & Q2-1979 & 10 \\
\hline MI & Q4-1981 & Q4-1983 & Q2-1978 & 14 & Q4-1979 & 8 & Q1-1980 & 7 \\
\hline NV & Q1-1982 & Q3-1984 & Q1-1979 & 12 & Q3-1979 & 10 & Q4-1979 & 9 \\
\hline WA & Q1-1982 & & Q1-1979 & 12 & Q3-1978 & 14 & Q2-1979 & 11 \\
\hline NM & Q3-1982 & & Q1-1979 & 14 & Q3-1978 & 16 & Q3-1979 & 12 \\
\hline WY & Q4-1982 & Q1-1989 & Q1-1979 & 15 & Q2-1979 & 14 & Q2-1980 & 10 \\
\hline $\mathrm{CO}$ & Q3-1983 & & Q1-1979 & 18 & Q3-1983 & 0 & Q2-1979 & 17 \\
\hline $\mathrm{HI}$ & Q3-1983 & & Q1-1979 & 18 & Q3-1983 & 0 & Q2-1979 & 17 \\
\hline OK & Q4-1983 & Q3-1988 & Q4-1978 & 20 & Q4-1982 & 4 & Q2-1979 & 18 \\
\hline MS & Q1-1984 & & Q4-1978 & 21 & Q3-1984 & -2 & Q1-1979 & 20 \\
\hline LA & Q2-1984 & Q4-1988 & Q4-1978 & 22 & Q1-1984 & 1 & Q2-1979 & 20 \\
\hline MT & Q2-1984 & Q4-1987 & Q1-1979 & 21 & Q2-1984 & 0 & & \\
\hline AK & Q3-1984 & Q1-1990 & Q1-1979 & 22 & Q2-1983 & 5 & Q2-1982 & 9 \\
\hline ND & Q3-1985 & Q4-1988 & Q2-1978 & 29 & Q2-1983 & 9 & & \\
\hline TX & Q2-1986 & Q4-1988 & Q4-1978 & 30 & Q2-1984 & 8 & Q2-1980 & 24 \\
\hline$A Z$ & Q1-1987 & & Q1-1979 & 32 & Q1-1985 & 8 & Q2-1979 & 31 \\
\hline CT & Q2-1988 & Q1-1995 & Q2-1988 & 0 & Q1-1986 & 9 & Q2-1988 & 0 \\
\hline $\mathrm{NH}$ & Q1-1989 & Q4-1994 & Q4-1986 & 9 & Q1-1988 & 4 & Q2-1988 & 3 \\
\hline GA & Q4-1989 & & Q4-1978 & 44 & Q4-1988 & 4 & Q3-1981 & 33 \\
\hline MA & Q4-1989 & Q2-1992 & Q1-1988 & 7 & Q1-1986 & 15 & Q3-1987 & 9 \\
\hline ME & Q4-1989 & Q4-1994 & Q2-1988 & 6 & Q4-1987 & 8 & Q2-1985 & 18 \\
\hline NJ & Q4-1989 & Q4-1991 & Q4-1986 & 12 & Q4-1986 & 12 & Q3-1988 & 5 \\
\hline RI & Q4-1989 & Q2-1992 & Q4-1986 & 6 & Q1-1988 & 7 & Q3-1987 & 9 \\
\hline VT & Q4-1989 & & Q1-1988 & 7 & Q3-1988 & 5 & Q2-1989 & 3 \\
\hline NY & Q1-1990 & & Q4-1986 & 13 & Q4-1985 & 17 & Q2-1988 & 7 \\
\hline VA & Q2-1990 & & Q4-1978 & 46 & Q4-1988 & 6 & Q2-1979 & 44 \\
\hline CA & Q3-1990 & Q1-1995 & Q1-1979 & 46 & Q4-1988 & 7 & Q3-1990 & 0 \\
\hline MD & Q3-1990 & & Q4-1986 & 15 & Q3-1989 & 4 & Q1-1990 & 2 \\
\hline $\mathrm{HI}$ & Q3-1994 & Q4-1999 & Q1-1979 & 62 & Q3-1992 & 8 & Q2-1991 & 13 \\
\hline
\end{tabular}

Median values:

$\begin{array}{lcc}\text { All state booms } & 12 & 8 \\ & & 9 \\ \begin{array}{l}\text { States with peaks followed } \\ \text { by flat prices }\end{array} & 11.5 & 11 \\ \text { States with peaks followed } \\ \text { by falling prices }\end{array}$

Note: Table 2 shows all cases in which the nominal house price increase at an annual rate over a three-year period is greater than twice the state's long-term average. Shaded rows denote cases meeting the FDIC definition of a house price boom. Blanks entries indicate not applicable.

Source: See Figure 3 and text. 


\section{Table 3: House Price and Business Cycle Peaks}

\begin{tabular}{|c|c|c|c|c|c|}
\hline State & $\begin{array}{c}\text { House price } \\
\text { peak }\end{array}$ & $\begin{array}{c}\text { House price } \\
\text { decrease? }\end{array}$ & State Recession? & $\begin{array}{c}\text { Business cycle } \\
\text { peak }\end{array}$ & $\begin{array}{l}\text { Quarters by which } \\
\text { business cycle peak led } \\
\text { (lagged) house prices }\end{array}$ \\
\hline ID & Q4-1979 & & & & \\
\hline $\mathrm{OH}$ & Q4-1979 & & & & \\
\hline IN & Q1-1980 & & & & \\
\hline $\mathrm{MO}$ & Q2-1980 & & & & \\
\hline WV & Q2-1980 & & & & \\
\hline IA & Q3-1980 & Yes & & & \\
\hline OR & Q3-1980 & Yes & Yes & Q4-1979 & 3 \\
\hline WI & Q3-1980 & & & & \\
\hline KS & Q4-1980 & & & & \\
\hline NE & Q4-1980 & & & & \\
\hline VT & Q4-1980 & Yes & & & \\
\hline DC & Q2-1981 & Yes & & & \\
\hline CA & Q4-1981 & & & & \\
\hline MI & Q4-1981 & Yes & Yes & Q1-1979 & 11 \\
\hline NV & Q1-1982 & Yes & & & \\
\hline WA & Q1-1982 & & & & \\
\hline NM & Q3-1982 & & & & \\
\hline WY & Q4-1982 & Yes & Yes & Q4-1981 & 4 \\
\hline $\mathrm{CO}$ & Q3-1983 & & & & \\
\hline $\mathrm{HI}$ & Q3-1983 & & & & \\
\hline OK & Q4-1983 & Yes & Yes & Q1-1982 & 7 \\
\hline MS & Q1-1984 & & & & \\
\hline LA & Q2-1984 & Yes & & & \\
\hline MT & Q2-1984 & Yes & & & \\
\hline AK & Q3-1984 & Yes & Yes & Q1-1985 & (2) \\
\hline ND & Q3-1985 & Yes & & & \\
\hline TX & Q2-1986 & Yes & Yes & Q4-1985 & 2 \\
\hline$A Z$ & Q1-1987 & & & & \\
\hline CT & Q2-1988 & Yes & Yes & Q1-1989 & (3) \\
\hline $\mathrm{NH}$ & Q1-1989 & Yes & Yes & Q1-1989 & 0 \\
\hline GA & Q4-1989 & & & & \\
\hline MA & Q4-1989 & Yes & Yes & Q1-1989 & 3 \\
\hline ME & Q4-1989 & Yes & Yes & Q1-1989 & 3 \\
\hline NJ & Q4-1989 & Yes & Yes & Q1-1990 & (1) \\
\hline RI & Q4-1989 & Yes & Yes & Q1-1989 & 3 \\
\hline VT & Q4-1989 & & & & \\
\hline NY & Q1-1990 & & Yes & Q2-1990 & (1) \\
\hline VA & Q2-1990 & & & & \\
\hline CA & Q3-1990 & Yes & Yes & Q3-1990 & 0 \\
\hline MD & Q3-1990 & & Yes & Q2-1990 & 1 \\
\hline $\mathrm{HI}$ & Q3-1994 & Yes & Yes & Q1-1992 & 10 \\
\hline
\end{tabular}

Note: Table 3 shows all cases in which the nominal house price increase at an annual rate over a three-year period is greater than twice the state's long-term average. Shaded rows denote cases meeting the FDIC definition of a house price boom. Blank entries indicate "no" for house price decrease and state recession, and not applicable for business cycle peak and quarters of lead or lag.

Source: See Figure 1 and text. 